\title{
Botryosphaeria Stem Blight on Southern Highbush Blueberry in Florida ${ }^{1}$
}

\author{
Norma C. Flor, Douglas A. Phillips, and Philip F. Harmon²
}

Information contained in this publication is intended for Florida blueberry growers to use as a guide in the identification and management of Botryosphaeria stem blight on southern highbush blueberry (SHB).

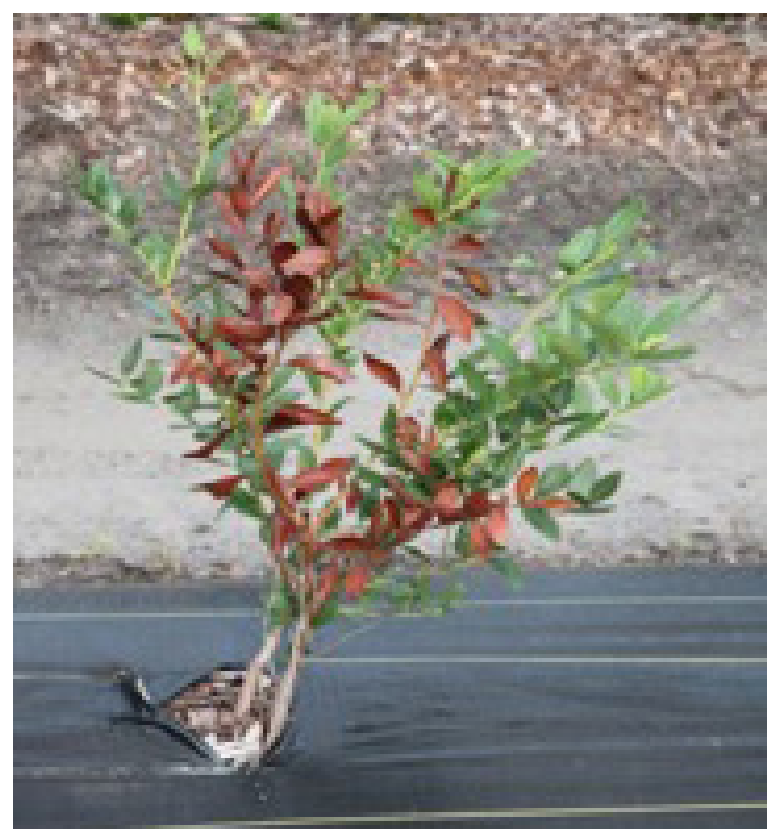

Figure 1. Symptoms of stem blight disease on southern highbush blueberry.

Credits: P. Harmon, UF/IFAS

\section{Introduction}

Vascular pathogens (fungal and bacterial) represent constant challenges for southern highbush blueberry (SHB) growers. Botryosphaeria stem blight is the most common and damaging fungal vascular disease on SHB in the southern United States, causing stem and cane dieback and reductions in yield. Advanced stages of this disease may cause premature plant death, which results in significant replanting costs for growers. Biotic or abiotic stresses from a variety of sources can make plants more susceptible to infection by stem blight pathogens. All SHB and rabbiteye blueberry cultivars are susceptible to stem blight, although cultivars do show differences in their level of susceptibility both under field conditions and in artificial inoculations.

Members of the Botryosphaeriaceae (Bot. family) that cause stem blight are well-known fungal pathogens of several woody host species in tropical regions worldwide. In Florida, Neofusicoccum ribis and Lasiodiplodia theobromae are the most important stem blight pathogens on SHB. However, names of fungi in the Bot. family continue to change as scientists learn more about this diverse group. Many references still refer to Botryosphaeria dothidea as the

1. This document is PP347, one of a series of the Plant Pathology Department, UF/IFAS Extension. Original publication date April 2019. Visit the EDIS website at https://edis.ifas.ufl.edu for the currently supported version of this publication.

2. Norma C. Flor, postdoctoral researcher, Plant Pathology Department; Douglas A. Phillips, blueberry Extension coordinator, Horticultural Sciences Department; and Philip F. Harmon, professor, Plant Pathology Department; UF/IFAS Extension, Gainesville, FL 32611.

The use of trade names in this publication is solely for the purpose of providing specific information. UF/IFAS does not guarantee or warranty the products named, and references to them in this publication do not signify our approval to the exclusion of other products of suitable composition.

Use pesticides safely. Read and follow directions on the manufacturer's label. All chemicals should be used in accordance with directions on the manufacturer's label.

The Institute of Food and Agricultural Sciences (IFAS) is an Equal Opportunity Institution authorized to provide research, educational information and other services only to individuals and institutions that function with non-discrimination with respect to race, creed, color, religion, age, disability, sex, sexual orientation, marital status, national origin, political opinions or affiliations. For more information on obtaining other UF/IFAS Extension publications, contact your county's UF/IFAS Extension office. 
cause of stem blight of blueberry. Although important for research and breeding efforts, determining which species occur on a farm currently has no practical significance or implications for management.

\section{Disease Cycle and Epidemiology}

Members of the Bot. family can be saprophytes (feeding on dead or decaying plant material) or endophytes (colonizing living plant tissue without causing disease symptoms). In their saprophytic stage they can survive on decaying plant tissue in natural areas and production fields, producing spores capable of being spread on wind currents and via rainsplash. As endophytes, they can remain on and in healthy plant tissue without causing any disease symptoms (latent). However, certain environmental conditions or plant stresses can help these fungi shift to become pathogens that initiate disease. On woody hosts (including blueberries), these pathogens enter through natural openings (lenticels and stomata) or wounds. Otherwise-healthy plants mount defenses and stop infections from developing into severe disease symptoms. Plants under abiotic and biotic stress such as drought, defoliation, insufficient winter chilling, overfruiting, nutrient deficiency, winter freeze, herbicide damage, other diseases, or insect pest damage are more susceptible, and infections can develop into severe symptoms including cane dieback and plant death.

In Florida, the summer and early fall months (May to October) with hot and humid weather are very favorable for growth of the stem blight pathogens. Mycelia and spore-producing reproductive structures (pycnidia and perithecia) are formed in dead bark and wood but are rarely if ever observed. Spores of N. ribis and L. theobromae can be dispersed from infected to healthy plants by water splash or carried by wind. Stem blight pathogens are very common throughout the state in all production areas and cannot be excluded. Spore germination is favored by high $(98 \%-100 \%)$ relative humidity and frequent rainfalls. After spore germination, fungal mycelia infect the plant through natural openings or enter into the plant's conductive xylem tissues through wounds. Expression of symptoms usually occurs 4-6 weeks after infection and often corresponds to the first droughty periods in summer or fall. Because the xylem becomes partially or completely blocked, symptoms mimic extreme drought stress in the infected canes, or in the whole plant for crown infections.

\section{Symptoms}

External symptoms of stem blight on individual canes occur when the leaves no longer get enough water. Wilt and yellowing are quickly followed by reddening and death of attached leaves that take on a dry appearance (Figure 1). Although the fungus infected the plant weeks earlier, the wilting process occurs rapidly, with leaves remaining on the dead canes. This rapid blight of one or a few canes on plants is sometimes referred to as "flagging." The flagging of dead canes on a few scattered plants down a row is often the first stem blight symptom identified by growers.

To confirm stem blight as the cause of the cane death, growers can look for the characteristic internal wood discoloration symptoms in cross-sections of the cane. Use loppers or hand pruners to cut near the dead leaves, then make additional cuts below and toward the crown (the junction of root and stem tissues at the ground). The pecan-brown discoloration is typically observed in pie-piece shapes where the fungus is in the xylem (left stem, Figure 2). For cane infections, continue to cut down below the infection until there is clean wood (right stem, Figure 2 ). For crown infections, the discolored area often increases with additional cuts toward the crown. Eventually, the pathogen colonizes crown tissue, spreading into multiple canes and major roots, and the plant will die (Figure 3).

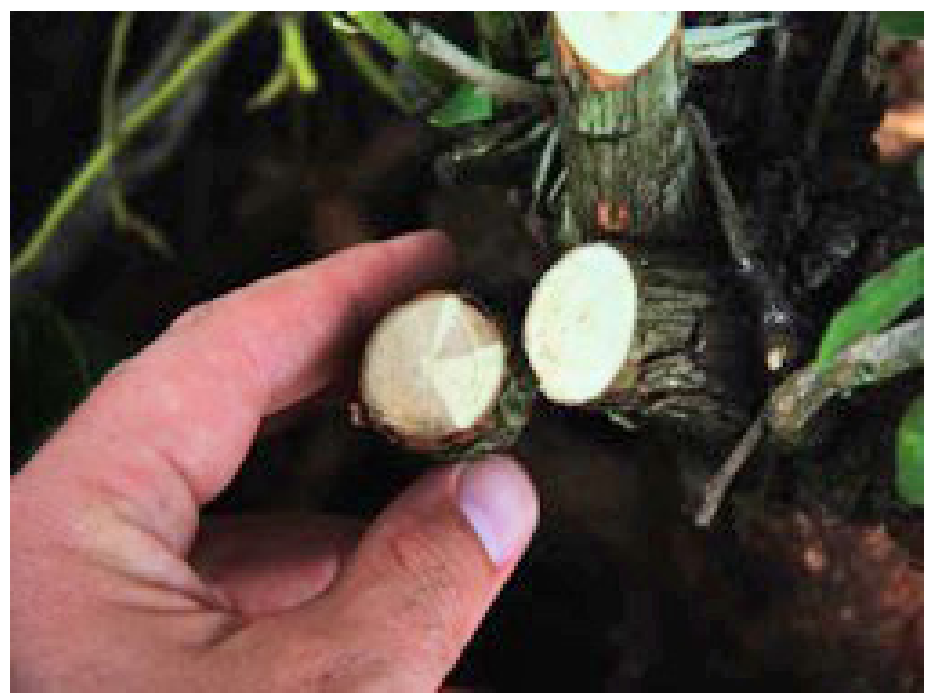

Figure 2. Internal symptoms of stem blight disease in a cane crosssection.

Credits: P. Harmon, UF/IFAS 


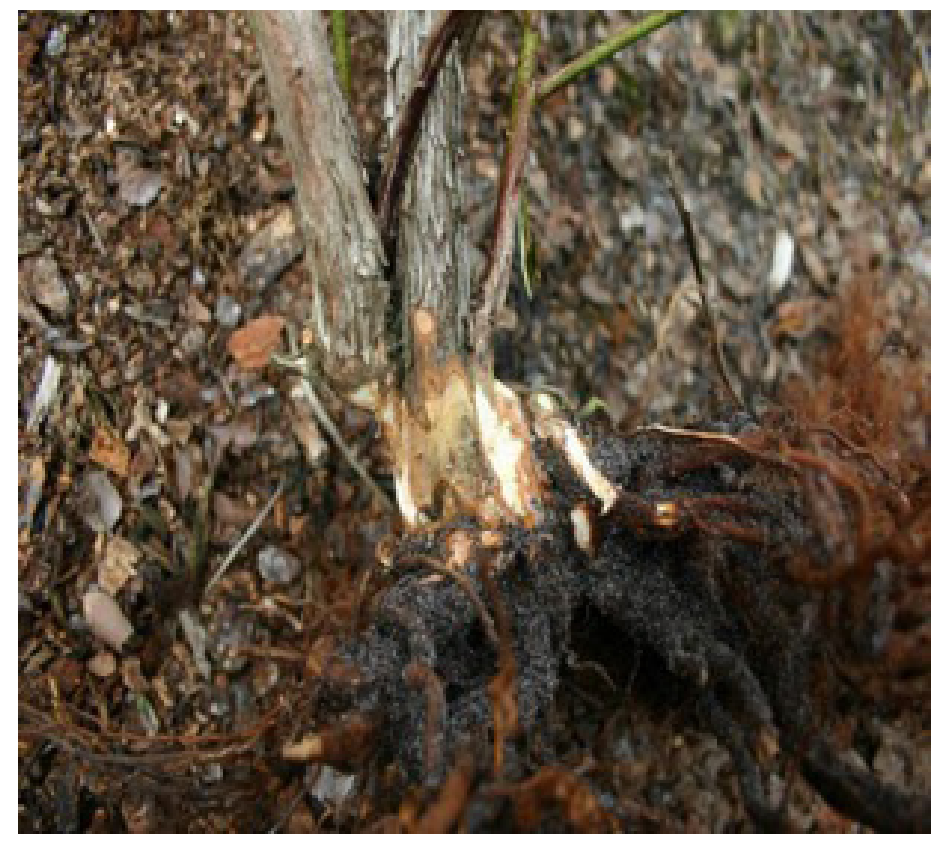

Figure 3. Internal vascular discoloration symptom of stem blight disease in the crown

Credits: P. Harmon, UF/IFAS

\section{Disease Management}

No one product or practice can prevent all stem blight losses. Stem blight can be difficult to manage and requires an approach that integrates good horticultural inputs with good pest management practices. Growers can avoid severe stem blight outbreaks associated with some stresses through horticultural inputs, but other factors out of their control such as extreme weather events (flooding associated with hurricanes, for example) also contribute to stem blight losses. No one blueberry variety is immune to stem blight; any variety can become quite susceptible under a wide range of individual and varying stresses, including environmental conditions, insects, other diseases, chemicals, etc. The more resilient to plant stress a variety is in general, the less likely stem blight will be a problem. The following guidelines will help reduce the chances that stem blight will become a major limiting factor to blueberry production on a farm.

\section{Irrigation Management}

The single most important factor for stem blight management is good irrigation practices. Drought stress can quickly lead to severe and widespread stem blight problems. This has been well-documented for many crops affected by pathogens in the Bot. family, and research has shown that the effects of drought stress can continue to increase disease likelihood and severity long after water is restored to the plant. In Florida production, raised pine-bark beds are generally used to increase drainage and prevent
Phytophthora root rot. Pine-bark beds or incorporation of pine bark lowers the $\mathrm{pH}$ of native sands and provides needed organic matter to optimize blueberry growth, but pine bark has limited water-holding capacity. Where the native soils are not favorable for blueberry, root zones rarely extend below the pine bark. As plants increase in size, their rates of water use (evapotranspiration) increase, which can lead to drought stress despite soil moisture below the bed because their roots aren't accessing the moister soil under the pine bark. Careful thought and design should be put into the irrigation system to avoid drought stress. Double-row drip irrigation, landscape fabric, and pine bark incorporation as well as topdressing before planting have all been successfully used. Overhead irrigation should be reserved for freeze protection and supplementing drip irrigation systems during droughty weather. Overhead irrigation can be effective but can also significantly contribute to other fungal and algal leaf and stem diseases. For more information on irrigation design, costs, and use for freeze protection, consult the following publications:

Florida's Commercial Blueberry Industry (https://edis.ifas. ufl.edu/ac031)

Establishment and Production Costs for Southern Highbush Blueberry Orchards in Florida: Enterprise Budget and Profitability Analysis (https://edis.ifas.ufl.edu/fe1002)

Protecting Blueberries from Freezes in Florida (https://edis. ifas.ufl.edu/hs216)

\section{Managing Other Root and Crown Diseases and Pests}

Stem blight is often a secondary issue that follows another disease or pest. If stem blight becomes an issue in a field, check for and address these other contributing issues as part of a stem blight management plan. Look for diseases that affect the root systems of blueberries, because they can reduce the ability of plants to take up water, which can lead to drought stress and stem blight. Insect pests that feed on or in roots and stems have similar effects and create wounds that can allow stem blight pathogens to enter.

Specific examples and management resources include:

\section{PHYTOPHTHORA ROOT ROT}

Root rot typically is most severe in low and poorly drained areas of a farm. Root rot is managed by mitigating waterlogged soils through drainage and raised bed construction. Fungicides with the active ingredient mefenoxam, such as Ridomil Gold SL, are recommended where root rot occurs 
and are applied twice yearly through drip irrigation or as a band application directly to the bed. Phosphorous acid products referred to as "phites" are also recommended as summer foliar sprays to help combat Phytophthora root rot and fungal leaf diseases. Example products and detailed rates and uses are covered in the current Florida Blueberry Integrated Pest Management Guide (https://edis.ifas.ufl.edu/ hs380).

\section{BACTERIAL WILT}

Where bacterial wilt occurs, Ralstonia solanacearum rots roots and clogs water flow in xylem, mimicking drought stress symptoms. Drought-stressed plants with bacterial wilt become very susceptible to stem blight. The variety 'Arcadia' rarely gets stem blight disease without also having bacterial wilt. Wilt is a relatively new problem that has been most severe in south Florida. For more details on bacterial wilt, see Bacterial Wilt of Southern Highbush Blueberry Caused by Ralstonia solanacearum (https://edis.ifas.ufl.edu/ pp332).

\section{DIAPREPES ROOT WEEVIL AND FLATHEADED BORERS}

Diaprepes weevil larvae feed on roots of blueberry. The larvae channel into and bore holes through roots, creating wounds and disrupting water uptake. Wounded and water-stressed plants are susceptible to Bot. pathogen infection and stem blight disease development. Recently (2014), flatheaded beetle borers have been found feeding on aboveground stems of blueberry in Florida. These larvae tunnel under bark, creating channels similar to those caused by Diaprepes larvae, but on aboveground stems. These wounds disrupt the cane's vasculature and serve as an ideal entry point for stem blight pathogens to get into the crown of blueberry plants. Managing these two insect pests will help reduce plant stresses and stem blight losses as well. Resources include:

\section{Diaprepes Root Weevil (https://edis.ifas.ufl.edu/in151)}

Beetle Borers in Blueberry (http://blogs.ifas.ufl.edu/ entnemdept/2018/07/06/beetle-borers-in-blueberry/).

\section{LEAF DISEASE MANAGEMENT AND FLOWER BUD DIFFERENTIATION}

Fungal leaf diseases do not directly lead to stem blight problems; however, defoliation after harvest and before flower bud initiation in fall causes plant stresses and lowers yield the following spring. Severe defoliation that leads to carbohydrate stress during the next bloom and fruit cycle has anecdotally been associated with increases in stem blight after harvest, so managing foliar diseases through flower bud differentiation in fall is recommended.

Carbohydrate stress during fruit production also can occur with certain varieties that tend to set more fruit than the bushes' leaves can support. This is generally referred to as overfruiting and underleafing. Poor leafing can be due to plants receiving insufficient chilling and can be mitigated by using hydrogen cyanamide on tolerant cultivars in the deciduous production system.

In the evergreen production system, managing leaf diseases through early winter can help improve overall plant health and may help prevent severe stem blight outbreaks. For more information on flower bud differentiation and hydrogen cyanamide use for southern highbush blueberry, see: http://edis.ifas.ufl.edu/hs220.

\section{Reducing Inoculum and Fungicide Application}

The following practices may help reduce disease in some cases but do not offer acceptable control unless other stresses and inputs (above) are also addressed. Use healthy, vigorous plants that are free from disease when purchased; if they look questionable or have dieback, don't use them. During and after establishment, removing dead or dying plants from production fields is generally a good cultural practice implemented to decrease the amount of fungal pathogens (inoculum) in a field. It is not uncommon for $1 \%$ to $3 \%$ of plants to fail to establish. Stem blight sometimes plays a role, and the pathogen can often be isolated from a sample sent to the UF/IFAS Plant Diagnostic Center. But also check for girdling roots, improper planting depth, accidental nonselective herbicide overspray, and clogged drip emitters. If needed, correct these problems and replant as soon as possible.

For plants showing flagging of a single cane, selectively pruning out diseased canes by cutting a few inches below the internal discoloration may help slow infection spread within a plant. Disinfect pruning shears between plants when cutting out disease to prevent spread. However, if you see sections of discoloration getting bigger the further down the cane you prune, the crown is probably infected, and the plant is not likely to survive. Remove cane cuttings and dead or dying plants from the field and burn, compost, or bury them. Do not leave cuttings and dead plants in the row middles for extended periods, chip dead plants for use as mulch, or create dead plant piles upwind of production fields. 
On their own, fungicides have not been successful tools to manage stem blight. This is due to a number of factors including the limited abilities of plants to take up and translocate most of the potentially effective fungicides to where the infections have occurred, and that the pathogens are so common even inside healthy plants. The bottom line is that stressed plants will develop stem blight and die even with a good fungicide spray program if the stress is not addressed. Fungicides can help to protect fresh pruning wounds from invasion by stem blight fungus that is already in the field or latently in the plant. The best time to apply fungicides is immediately after hedge-pruning the plants. Application the day before pruning does not reduce disease as much as spraying immediately following pruning but is better than not spraying at all. Most fungicides labeled for summer leaf-spot prevention also help protect pruning cuts from stem blight. Specific examples include a captan product alone or tank-mixed with a phite (an example is Prophyt). Timing this tank-mix application at hedging will also give some protection from Phytophthora root rot and Septoria leaf spot diseases. Other fungicides routinely used in a summer spray program should also help, but keep in mind that good irrigation and plant stress management must also be addressed. Currently there are no resistant varieties; however, the UF/IFAS Blueberry Breeding Program is continuing collaborative efforts to work towards more durable varieties.

\section{Summary}

Stem blight is the most common disease that kills our blueberry bushes in Florida. In most cases, stem blight finishes the job, but other stresses play a lead or contributory role. When stem blight starts showing up in a production field, first check for all of the above discussed stressors, diseases, and pests. Once identified, developing an integrated and comprehensive disease management plan will help you stay one step ahead of stem blight.

\section{References}

Olmo, D., J. Armengol, and M. León. 2016. Characterization and Pathogenicity of Botryosphaeriaceae Species Isolated from Almond Trees on the Island of Mallorca (Spain). Plant Disease. 100 (12): 2483-2491.

Polashock, J. J., F.L. Caruso, A. L. Averill, and A. C. Schilder. 2017. Compendium of Blueberry, Cranberry and Lingonberry Diseases and Pests. Second Edition. American Phytopathological Society, St. Paul, Minnesota, USA.
Tennakoon, K. M. S., H. J. Ridgeway, M. V. Jaspers, and E. E. Jones. 2015. Herbicide Injuries on Blueberry Provide Suitable Infection Sites for Neofuscicoccum ribis. New Zealand Plant Protection. 68: 411-414.

Tennakoon, K. M. S., H. J. Ridgeway, M. V. Jaspers, and E. E. Jones. 2018. Factors Affecting Neofuscicoccum ribis Infection and Disease Progression in Blueberry. Eur J Plant Pathol. 151: 87-99.

Williamson, J. G., P. F. Harmon, O. E. Liburd, and P. Dittmar. 2017. Florida Blueberry Integrated Pest Management Guide. HS1156. Gainesville: University of Florida Institute of Food and Agricultural Sciences. https://edis.ifas.ufl.edu/ hs 380 